\title{
Transformation and self-identity: Student narratives in post-apartheid South Africa
}

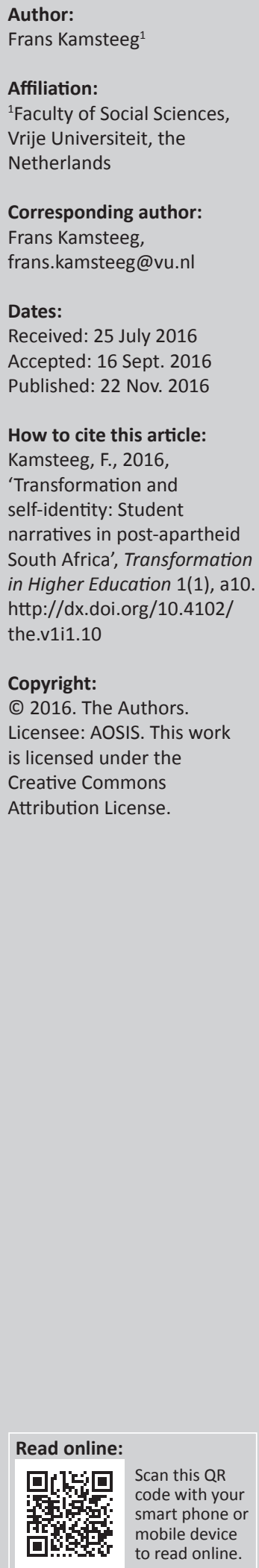

\begin{abstract}
Organisational change processes are by nature complex and often highly contested. This is particularly true of the transformation South African institutions of higher education have been going through since the end of the apartheid era. Using a narrative approach, this article presents a multi-faceted range of stories by the University of the Free State (UFS) students who took part in a particular leadership programme designed to make a contribution to institutional, and even, societal change. The plurivocality of the identity work the UFS students' stories display is based on their ethnic, gender and class diversity. It is the context-sensitive 'tales of the field' they tell that might help to understand why the transformation concept as well the various transformation-driven practices in higher education are so ambiguous and contested.
\end{abstract}

\section{Introduction}

World-wide, higher education is changing and increasingly characterised by diversity (Paradeise \& Thoenig 2013). While this diversity has the potential of enriching the academic community and, in a broader sense, society as a whole, the underlying processes are often far from unproblematic. Higher education institutions sometimes stress the benefits of diversity for their organisations, pointing to their potential of safe spaces for reflection (Roux 2012). Yet, the very concept of diversity can also be a source of contradiction, inequality and exclusion, and challenge the ideal of a cohesive academic community (Brink 2010; seen also Cross 2004). The ways in which higher education institutes deal with change coming with the challenge of diversity can be understood by studying the experiences of its main protagonists. This article aims to demonstrate that student narratives are well suited to illuminate the complex, multifaceted, ambiguous and contested character of (organised) change processes, which are seldom straightforward and self-evident (Brown, Gabriel \& Gherardi 2009:324; Humphreys \& Brown 2002; Thomas \& Hardy 2011; Thomas, Sargent \& Hardy 2011).

Students have always raised their voices on the choices their institutions make, but the reshaping of higher education in South Africa since the African National Congress (ANC) come to power has renewed student attention - most visibly in the multiple manifestations of campus protests in 2015 and 2016 - for the important role education plays in the country's development. The reasons for protest are manifold, but generally revolve around diversity and transformation, or lack thereof. Despite major government instigated restructurings - the most noticeable being the 2004 merger operation - many university cultures have shown a notorious slow degree of change compared with the pre-1994 situation (Aina 2010; Balintulo 2003; Chetty \& Merrett 2014; Cloete 2014; Cross 2004; Higgins 2013; Jansen 2009; Jawitz 2010; Kamsteeg 2011; Keet \& Nel 2016; Seabi et al. 2012; Soudien 2008; Tabensky \& Matthews 2015; Verwey \& Quayle 2012; Walker 2005a; 2005b; Walker \& Loots 2016).

This article presents narratives of self-identity of students from the University of the Free State (UFS), a formerly all-white and Afrikaans-medium taught university that is actually going through a critical transition phase (Keet \& Nel 2016). In order to shed light on how this change process is understood by those who are directly concerned, this article presents the narrative reflections of students who participated in a university-wide change project designed to make an explicit contribution to rebuild and transform the fabric of South African society.

\section{South Africa's post-apartheid higher education transformation}

Except for a relatively quiet period in the early 20th century, South Africa's higher education history has been a turbulent one, particularly so in the period of official apartheid from 1948 
onwards. During this period, higher education developed into a system of inequality, with disproportionately dispersed institutions varying a great deal in size, student enrolment, research capacity, funding, quality of management, etc. The major divide was between historically advantaged institutions and historically disadvantaged institutions as a result of the regime's interventionist policies to establish racial segregation in tertiary education as elsewhere in society. Since 1994, the government and its successive Ministers of Education have viewed (higher) education as a vehicle for effecting societal transformation and redressing the legacy of apartheid. The National Commission on Higher Education, instituted by the government in 1996, initiated a programme of policy change which in 1997 culminated in a White Paper on Higher Education (Department of Education 1997; see also CHE 2007; Jansen 2003; Jansen et al. 2002). This White Paper defined the 'size and shape' of the new system, emphasising programme-based planning and the need for institutional collaboration. Quality assessment by a proposed Council on Higher Education was meant to provide a sound basis for decisions on structural rearrangements; mergers were not really announced yet (Jansen 2003:3). The issue came to the fore only in 1999 when the new Minister of Education, Kader Asmal, was appointed. The idea of linking institutional restructuring of the system and social redress gained further purchase and force in 2002 with the Department of Education's The Restructuring of the Higher Education System in South Africa, which proposed a farreaching programme of mergers as an appropriate mechanism to bring about transformation, equity, sustainability and productivity (Balintulo 2003:457). The same document also provided concrete merger goals and a list of institutions that had to be merged. Subsequent policy documents developed the idea of institutional mergers as the principle means to reach the desired goals of reorganisation: social development, equity and quality, including the building of new institutional cultures and identities (Higgins 2007; Jansen 2003:9). Practically, the entire sector protested against the Ministry's top-down approach but, in 2004, the government-mandated merger programme had effectively reduced 36 institutions of higher education to 23:11 traditional universities (offering theory-oriented degrees), 6 universities of technology (offering vocational diplomas and degrees) and 6 comprehensive universities (offering a combination of both qualifications).

The merger project introduced a number of major policy measures intended to reduce inequality and foster internationalisation in one single operation. Yet, the government underestimated the social and cultural effects of the past, and the extent to which particular groups and institutions had vested interests to defend. It was only to be expected then that after so many years in which the government's explicit steering role had been the organisation of segregation, a change towards deliberate transformation through merging would produce resistance, particularly at the universities who had been practicing segregated education, including the UFS (for the North-West University, see Kamsteeg 2008; 2011).

\section{Transformation at the University of the Free State}

The UFS, established in 1904 as the Grey University College with only six students, is one of the oldest universities in the country, serving as a practically all-white student and staff institution before and during the apartheid era. When in 1993 the university introduced a parallel-medium language policy, the introduction of English caused a significant increase in the enrolment of black students. Yet, integration was far from achieved. Most Afrikaans students still take their classes in Afrikaans, whereas black students prefer the English version of the lectures. Campus life also remains divided with black and white residences. Still in 2005, the then rector acknowledged that the main campus actually consisted of two spaces, with a student population divided along racial lines.

By 2007, the student population had grown to 27 000, and today the number has grown to 33000 , divided over three campuses. In 2003, the university merged with the Qwaqwa Campus - a former 'homeland' university situated in the Eastern Free State - and, in 2004, the South Campus was added to the broader institution. With these two campuses added to the main city campus, UFS complied with the SA government's higher education policy. By now, it is a middlerange university with over 4000 faculty and support staff, divided over seven faculties and more than a 100 departments.

Key to understanding the symbolic role the Bloemfontein university fulfils in the overall university transformation process in South Africa is the racist incident that took place at UFS in 2008. The so-called 'Reitz incident' took place during the initiation period in one of the main campus' traditional student residences. Three black workers were humiliated in what the three white male student perpetrators considered a practical joke. The case was blown up when the students showed their acts on YouTube, thus causing a major outrage in the university and in fact the whole country. The incident showed that 14 years after the end of apartheid, racial differences in South Africa's universities were still alive. This only confirmed an earlier observation by Jonathan Jansen, appointed as UFS's vice chancellor and rector after the Reitz incident in 2009, that universities had perhaps made steps towards racial desegregation but had been far less successful in achieving the ideal of institutional culture integration, including accommodating and affirming racial diversity and differences (Jansen 2004:122). In order to tackle the deeper problems he considered Reitz to represent, he took a number of decisions, not so much to talk about the Reitz Four, but rather 'about the Reitz in all of us'. The first was the establishment of an interdisciplinary Institute of Reconciliation and Social Justice, to coordinate research and public debate on the very issue of institutional transformation and human rights, now led by Prof. Andre Keet, with the explicit goal of attaining 'excellence in academic achievement and in human reconciliation' (UFS 2016) and to contribute to the task of transforming the historically white university into a non-racial environment. 
Eight years after the Reitz incident that made UFS headlines, the university's student population has turned predominantly black, while public debates about the state of transformation are regularly held, culminating in a Higher Education Transformation Colloquium hosted by UFS in Bloemfontein in 2013. Members of the governmental Transformation Oversight Committee, vice chancellors of different South African universities, UFS staff and students discussed the future of the South African Higher Education system in a 3-day meeting. Their preliminary conclusion was that universities face a persistently high dropout rate among first-year students, suffer from a lack of adequate funding as well as poor preparation at the high school level, still share diversity-hostile institutional cultures and, finally, struggle with rigid curricula and lack of academic discipline amongst its students. Much like what Jansen had already concluded in 2004, the colloquium's conclusion regarding the transformation of the Higher Education System particularly held the adverse campus culture responsible for the underperformance of black students.

A more silent initiative taken by UFS rector Jansen in 2010 was the F1 (first years) Leadership for Change Program, a 'study abroad program of short duration available to students of all ethnicities, enabling them to personally experience models of integration across lines of culture, colour and language' (UFS 2016). The programme, originally targeted at 75 first-year students per year, has selected students for an intense internal training programme culminating in a 2-week study abroad experience in one of UFS overseas university partners in the USA, Europe and Japan. The programme was hoped to produce a visible contribution to equip students with the skills and attitude to become leaders in the new South Africa. A huge billboard at one of the campus entrances in Bloemfontein explicitly refers to this vision (see photo). During four consecutive years (2012-2016), diverse (gender, race, discipline) groups of between 6 and 12 students actively took part in the Amsterdam University College's Global Diversity Experience course. Over the year, several former F1 programme students managed to obtain leadership positions, for example, in the student representative councils. Some became also active during the student protests in March 2016, against the very issues that were raised in the conclusions of the 2013 Transformation Colloquium. After some violent confrontation, UFS campus management decided to fence off the campus with barbed wire (see Figure 1), while student leaders organised regular debates on 'decolonising the curriculum' and changing 'campus culture'.

\section{Making sense of transformation through narratives of self-identity: A methodological note}

Narrative modes of interpretation make no absolute claims of truth, but rather suggest verisimilitude, endowing experience with meaning through the careful association of concrete (bottom-up) stories which are historically contextualised (Boje 1995; Brown et al. 2009; Czarniawska 1997; Gabriel 2000; Tsoukas \& Hatch 2001:983). In this view, people in organisations lead storied lives, meaning that organisational actors present their narratives as accounts of meaningful events 'with plots that weave together complex

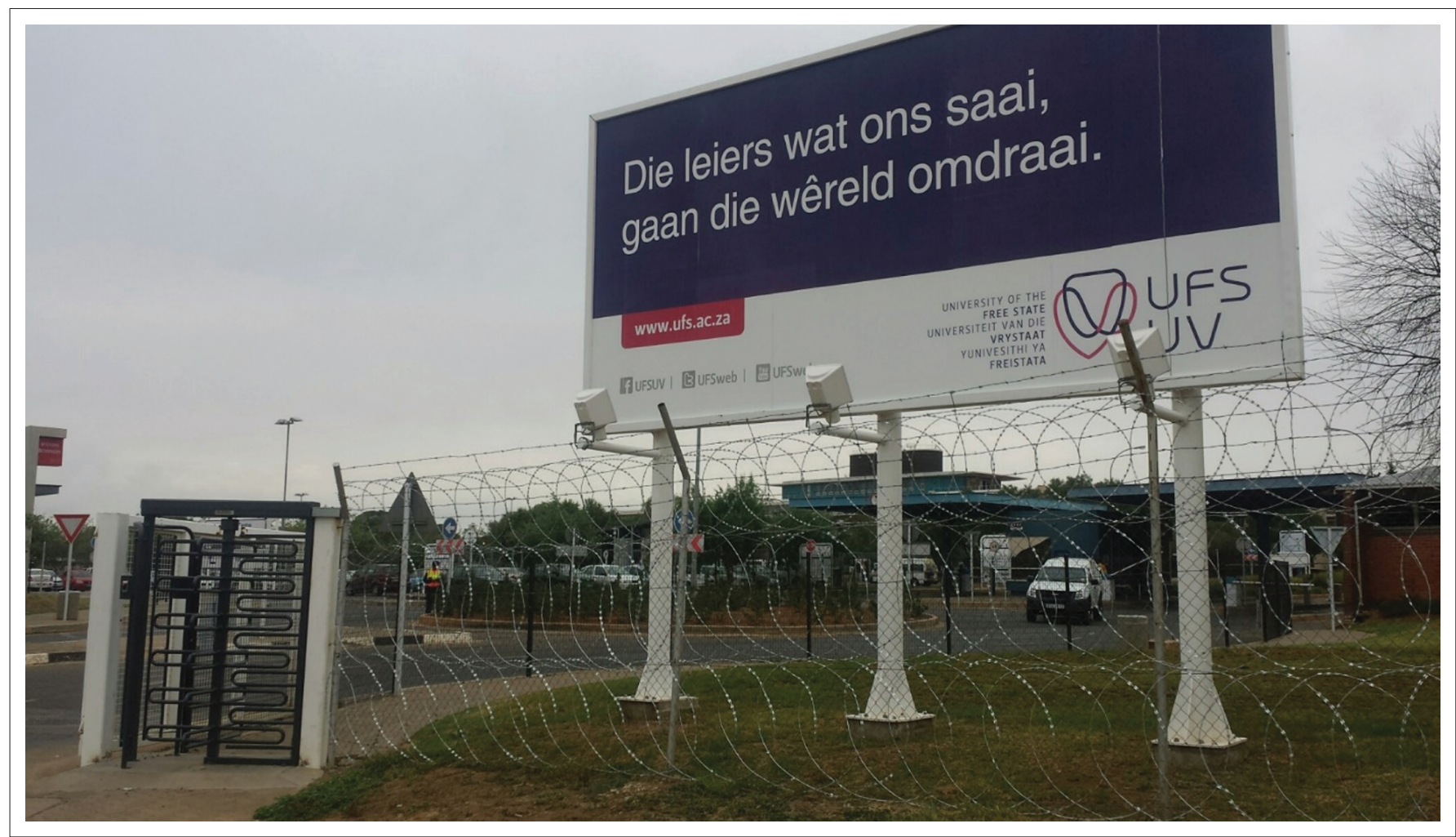

Source: Photograph by the author

FIGURE 1: The leaders we sow will change the world. 
occurrences into unified wholes that reveal significant instances of organizing, or organizational becoming' (Brown et al. 2009:325).

Organisations are socially constructed spaces where sensemaking actors constantly change organisational reality (Bate 1997; Van Maanen 2010). This sensemaking always takes place in an environment where meaning has to be constantly negotiated (Czarniawska 1997). The complexity of transformation processes, particularly in academic institutions, shows itself in the language used by the actors involved. Vaara (2002; 2003; Risberg, Tienari \& Vaara 2003) stresses the role of narratives as central to the understanding of the social construction of organisational phenomena. Like Tsoukas and Hatch (2001), he shows that narrative analysis allows linking discursiveness to diverse subject positions and identities (Vaara 2002:215-217). In his view, both success and failure versions of narratives can be either overly optimistic or deeply pessimistic, as meaninggiving actors are constantly framing and reframing the question of failure and success (2002:239), in what Brown and Humphreys (2003) call epic and tragic tales. The latter build their analysis on the type of storytelling approach advanced by Gabriel (2000) who argued that an analysis of these tales produces powerful insights into the various strategies organisational actors deploy in the battlefield of meaning production (see Bate 2004; Beech \& MacIntosh 2012; Boje 2008).

Based on a broad research review in organisation studies, Mats Alvesson (2010) presented a set of metaphorical images of self-identity, constructed in organisational contexts. These self-identity constructions are important devices for individual actors to position themselves - in various degrees of ambiguity and coherence - vis-à-vis the often messy contexts they live in (p. 17). Central to this approach of identity is the individual as storyteller (homo narrans) who follows Giddens' view on self-identity conceptualised as 'a reflexively organized narrative, derived from participation in competing discourses and various experiences, which is productive of a degree of existential continuity and security' (1991:5). The 'reflexively organized narrative' then is built out of what Alvesson calls 'cultural raw material: language, symbols, sets of meanings, values, etc.' (Alvesson 2010:11) through empirical (field)work. The seven images distinguished by Alvesson are 'self-doubters', 'strugglers', 'surfers', 'storytellers', 'strategists', 'stencils' and 'soldiers' (2010:7). The first three images refer to an individual context with insecurity, ambiguity and fluidity as the main characteristics, whereas the last three are more collectively contextualised and show some more coherent and robust characteristics. The middle image - presenting the actor as primarily a storyteller - is the pivotal position and the root metaphor of all others (p. 20), a view that is supported in Yannis Gabriel's Storytelling in Organizations (2000), where it is argued that through stories deep, often hidden, meanings held by organisational members can be retrieved.
In the following sections, the ongoing process of selfidentity constructing through storytelling by UFS F1 students is conceived and presented as self-identity work, which 'refers to people being engaged in forming, repairing, maintaining, strengthening or revising the constructions that are productive of a sense of coherence and distinctiveness' (Sveningsson \& Alvesson 2003:1165; Watson 2008). In the South African context, Jansen et al. (2002) similarly collected a series of contrasting educational narratives and counternarratives produced by managers and faculty of a complex institutional merger in an Eastern Cape higher education institution. Their presentation of stories by the various university groups subjected to the consequent institutional change displays a fierce discursive struggle through explicit identity work (2002:421ff.). Similarly to Walker's (2005a) account of race narratives among postapartheid university students at UFS (Walker 2005a), the present study locates student self-identity narratives into a layered and contextualised perspective on the wider organisational and societal arena in which the struggle over (the meaning of) change and transformation in South Africa's educational sector is played out (Kamsteeg 2011; Kamsteeg \& Wels 2012).

The narratives presented below give a multifaceted and diverse picture of how UFS students make sense of the changes the university is going through since the mid1990s, and more precisely since 2009 under the leadership of its rector and initiator of the leadership programme, Jonathan Jansen. These narratives essentially concern changes in the campus culture of the university in Bloemfontein, and I try to make sense of students' sensemaking efforts (Brown, Patrick \& Nandhakumar 2008). Student narratives are particularly important for studying campus culture, because they do in a way 'predict' the future of the university, as it is also explicitly mentioned in the rationale of the F1 leadership programme. ${ }^{1}$ Of course, the present staff and faculty are also, and probably even stronger, bearers of campus culture, but they are less explicitly targeted as change agents by the university leadership, which is perhaps one of the reasons for its slow change path (Higgins 2007; 2013).

The research for this study is based on ethnographic fieldwork among and interviews with UFS F1 students over the years 2012-2016. In the conclusion, I will draw parallels with Walker and Loots' (2016) study on UFS's first F1 student cohort, and on journalist Bryson's recent It's a Black and White Thing (2014), which is largely based on stories by the first UFS F1 student cohort. In this study, I predominantly use narratives from F1 students who came to Amsterdam as part of the exchange programme. The reason to do so is twofold. First, using data from a number of consecutive years gives the study a diachronic character, which, I believe, is fitting for a study on cultural transformation. Second, and perhaps more importantly, as host of the F1 groups in Amsterdam, I was able to develop a trust 1.http://www.ufs.ac.za/leadership-for-change-programme/leadership-for-changeprogrammes/home-page; visited 11 September 2016 
relationship with the students, which allowed me to 'shadow' (Czarniawska 2007; Kamsteeg \& Wels 2004) them as well as interview them, both in Amsterdam and during my field visits to Bloemfontein later on. My regular research visits to UFS, where I am hosted by the above-mentioned Institute of Reconciliation, and my involvement in the F1 programme as a foreign host, gave me a position of what I prefer to call engaged scholarship (Kamsteeg \& Ybema 2009; Van de Ven 2007). The narratives presented here are mostly based on interviews (recorded) and informal talks with some 25 students, held both in Bloemfontein and in Amsterdam. The narratives are both unique and representative, as they tell individual stories that contain elements shared by several others, also from students who went to universities in other countries, whom I met during various debriefing meetings I was able to participate in during my visits to Bloemfontein, and to the second Global Leadership Summit in 2015. At that meeting, UFS staff and hosts from all participating international universities met for 2 weeks with more than a hundred former participating students in extensive exchange programmes in Bloemfontein. At this occasion, it became clear that similarly diverse experiences of transformation are noticeable among students who went to Japan, the USA, Belgium or the Netherlands (Amsterdam). Therefore, I think I can claim that the narratives retrieved represent a range of diverse and reflect different views on transformation that is not limited to the Amsterdam student. The seven individual students' self-identities presented below, which are built around their involvement on campus and particularly their experiences with the F1 programme, are therefore to a significant extent representative for the programme at large.

\section{Seven student self-identity narratives}

Alvesson's emphasis on self-identity as an important concept for studying organisational identity allows for a more playful relationship between data, theory and concepts than organisational identification theories generally allow (2010:3-4). Juxtaposing different self-narratives, or images as Alvesson tends to call them, also makes it possible to depict the diverse, and even ambiguous identities people construct, particularly in situations that are themselves complex. The present transformation phase in South African higher education institutions can benefit from such a perspective that is conceptually broad and multifaceted. The concrete narratives I present were selected exactly because they reflect the wide number of meanings the concept of 'transformation' is given within the (UFS) context. Analogously to Alvesson, I distinguish seven narratives that broadly represent the selfunderstanding of F1 students vis-à-vis transformation at the campus they belong to. These self-identity narratives range from critically activist to opportunistically individualist. The selection of the narratives was to show exactly this diversity. I chose to present the most telling narratives (Table 1 gives an overview), but also respect the demographic, disciplinary and gender diversity of the total F1 population, which shows an overrepresentation of white students.
TABLE 1: Seven self-narratives.

\begin{tabular}{ll}
\hline Student $\uparrow$ - academic discipline & Self-identity narrative \\
\hline Hendrik $\$$ mixed race student, theology & The spiritual mediator \\
\hline Driekie, white student, drama & The hesitant Afrikaner \\
\hline Bonolo, black student, industrial psychology & The critical outsider \\
\hline Florence, white student, law & The English marginal \\
John, white student, law & The reflective politician \\
Dino, black student, economics & The born leader \\
Anisha, black student, accounting & The careerist woman \\
\hline
\end{tabular}

$\dagger$, Although the use of the concepts of race, ethnicity and colour is highly contested since 1994 , it is part of everyday life and very difficult to avoid, both by researchers and people in their daily talk. Race and colour still do matter in South Africa for the way people define their their daily talk. Race and colour still do matter in South Africa for the way people define their
identities, despite the fact that non-racialism has become the official policy in the country (Maré 2014; McDonald 2006). The very concepts are crucial to the transformation debate (Mare 2014; McDonald 2006). The very concepts are cr
and are also regularly used by the student of this study.

$\$$. The identity of the students is protected by using pseudonyms for all names and other references.

\section{The spiritual mediator}

Hendrik is a mixed race theology student living in one of the oldest student residences of the UFS campus which is now slowly being transformed into an ethnically mixed residence. He is from a less fortunate family in the Eastern Cape and told me I was the first with whom he has shared his story:

'I'm planning to do my thesis on anthropology and theology, because I have discovered that the bible has some great stories of cultural diversity. My ambition is to become a lecturer in academia, as I can convey a message pretty clearly. To realize this I will go again to Europe, come back to Bloemfontein and give back what I learned.'

Hendrik links his mother's advice to 'make a lot of people to look up to you and follow your example' directly to his leadership role in the F1 group that visited Amsterdam. He semi-jokingly tells that they deliberately sent him there:

'Why Amsterdam? Well, I don't know why, perhaps they thought this guy is a theologian, let's see how he will handle Amsterdam with all the challenges, the red light district, homosexuals, etc. I must say I now think I was blessed to be thrown in the deep, to learn about student life in Amsterdam.'

He strongly believes that this whole F1 experience has helped him to grow personally:

'It has made me think differently, cognitively and emotionally. I now act differently, because I feel that I need to be more informed. You know, knowledge is power, it feels like I need it to get to know people. I have changed and learned to put myself in uncomfortable positions, I take myself more out of my comfort zone. Like e.g. going into townships, learn from the blacks, how they do their trade.'

The clearest reference Hendrik made to the transformation concept is when he asked me about John Coetzee's novel Disgrace. He had read this book in Amsterdam and was eager to explain how reading this book changed his ideas about black people and white people in South Africa:

'It was such intense reading, because of the deep hidden message in that book about South Africa. I immediately thought of it this way, the father in the book first was close to his daughter but then they grew apart. The father represents the apartheid government and the daughter the black people in South Africa. He could have prevented it from going wrong, like we could 
have prevented apartheid, but we didn't. He knew that what he did was wrong, apartheid people knew they were wrong.'

He immediately goes on to tell that since he is back his life has changed, his focus is different:

'South Africa has been a disgrace, but what we are experiencing now it is 'amazing grace', how Mandela acted the way he did, disgrace is now slowly eliminated and I am part of it, by talking to other students, taking part in the F1, going into communities. My Pentecostal pastor teaches us that traditions are of value, but not if they refer to something wrong. I now see that e.g. some residence names, with names of old apartheid defenders, have to be changed. The UFS needs to uphold the image, can't have things on campus that are wrong.'

Hendrik stresses that he must make a contribution to the transformation process, take his responsibility for changing the campus culture, by speaking out and mediating between fellow students. Hendrik's stance on transformation clearly stresses both personal and collective responsibility; his religious motivation is a feature that is more often - although generally less explicitly - expressed by F1 students.

\section{The hesitant Afrikaner}

As a creative student, Driekie felt greatly at ease in Amsterdam where students are encouraged to critically discuss any issue they want, on an equal footing. This she had also learned in the F1 programme:

'They actually made me think differently, accept people as they are - I suppose that is what transformation is about. Now when I hear someone talking racism, I stand up and say it. I would not have done that before.'

Yet, she continues about race:

'But race will never not be a problem in South Africa. Cultural differences, how we see things, people don't talk about these things, when talking racism people immediately shut the doors. Here at the university we started talking about it, but not to a point that we are getting any better. Here, because all the problems we have had, the Reitz hostel incident, it has opened the doors, and we can't close them anymore, the keys have been thrown away. I have so many black friends now.'

But then she takes back a little and shows some cracks in her story:

'Now that the top management wants to change the name of student residences bearing the name of former Apartheid figures, everything is blown up again. They also decided black and white should go together in the residences, and that they are going to choose your roommate for you. People start to protest.

\section{Asked whether this affects her, she says:}

'Well, the two [black and white students, FK] can't really function together, because as people we are different. It's ok if we can choose, but when you are forced, actually I could not do it. I have done it, for two or three weeks, but there are differences. And that girl I lived with, she could speak Afrikaans, she was more white than black, because she spoke our language. I don't think I would ... [with someone who doesn't speak Afrikaans]. It's not racist, it's just my preference ...'
This self-narrative shows us an open-minded student, who is nevertheless strongly affected by what Jansen calls 'Knowledge in the blood' (2009) transmitted to her by her background in the Afrikaner tradition. She is hesitant about her transformation but rather outspoken in that the radical transformation demands she encounters at university are for her as an Afrikaner girl a bridge too far. In this respect, Driekie's story shows an ambivalence that many white Afrikaner students feel regarding the consequences of transformation, without wanting to be associated with militant conservative groups defending white people's rights.

\section{The critical outsider}

Bonolo is a third-year Sotho speaking off-campus living industrial psychology student. Since 2013, there is a place where off-campus people can gather between and after classes. She is one of the leaders in this residence, which in her opinion is one of the most diverse:

'We are proud to have a fully mixed residence; you will find everything here: black, white, boys, girls, English, Afrikaans, Zulu, gays, lesbians, etc. much like in Amsterdam!'

Bonolo went to Amsterdam with the F1 group led by Hendrik. In her opinion, he was a good leader, but she believes more female leadership should be stimulated in the programme. During the group activities in Amsterdam, she often stood up to speak for the group:

'Yes, more girls should stand up. There are sufficient leaders but they don't dare to run against a boy, particularly not if it is for a SRC position. But from my F1 group there are now several who go for the residence committees. I myself want to broaden my horizon, like Antjie Krog [famous white anti-apartheid writer and poet], and perhaps study anthropology. My ambition is to go abroad, do an international master and then return and change the university. There is so much to change, e.g. the language policy ... You can apply only if you speak Afrikaans. It is a shame.'

Bonolo ironically remarks that transformation is the first word that you learn at the university these days, but that it is often used in a purely rhetorical sense:

'Now I've heard they gonna pay us to tell transformation stories. I wish I had a proper story, but I just don't have one. I want true transformation, I miss Amsterdam.'

Her experience in Bloemfontein, and also with the F1 group in Amsterdam, provided that she deliberately chose to keep outside of what she considers a suffocating campus culture. At the same time, Bonolo refuses to translate her culturally critical views into political militancy, as she believes organised student groups are dominated by party politics.

\section{The English marginal}

Transformation is often regarded as bringing black people and white people together, yet since the days of the AngloBoer war differences between English-speaking people and Afrikaners are noticeable. This becomes clear in the story of 
Florence, a 22-year-old law student. Her school background gave her a position strongly diverging from her Afrikaner compatriots:

'In my English school, my class was very diverse so I am used to racial differences. I now attend classes in English, which means that I have classes with black people as well, whereas my Afrikaans friends only go to class with Afrikaans people, which are mostly white.'

Florence was well aware of the role language played in the residences through the position she took in her residence:

\begin{abstract}
'At first we asked some black girls that I knew in the residence committee, so that we would be able to attract other black people to the residence. If you walk in the house you cannot only talk Afrikaans the whole time. In our house meetings we now only speak English and with our committee meetings we speak English as well. So it has been a whole process of changing our routine actually.'
\end{abstract}

Florence also touches upon another diversity issue, notably the distance between on and off-campus living students. Much of the university policies are focused on the students living on-campus, but the large majority live elsewhere in the city. She points out that the strong focus on the residences is regrettable. A considerable group of students live off-campus and she thinks that they will never be part of the transformation process, because they do not even know about the challenges on campus. She gives an example:

'The other day I had attended a SRC dialogue session where all off campus students were invited as well, and from the more than 20,000 UFS off-campus students only around 100 students were present. They think student activity is not for them, and they never hear about what we are discussing on campus.'

Florence's narrative shows that whiteness and Afrikaans are often joint obstacles to transformation, marginalising students who want to break traditional boundaries by pleading for the binding role of English language.

\section{The reflective politician}

John, an English-speaking Law student, held transformation portfolio in the SRC after his participation in the F1 programme. $\mathrm{He}$ also works at the Institute of Reconciliation. His F1 experience has played a decisive role in his university career, raising his consciousness about university transformation:

'It has made me think about the sub consciousness of discrimination around us. I've learned to think before saying something. You must do things with your F1, if you don't, it is waste, but many just move back into their comfort zone. During my F1 visit we learned about LGBT and race. It really opened my eyes beyond UFS.'

Upon his return to Bloemfontein, he started his leadership career:

'You come back to campus, and you are comfortable again. We started making it a bit more uncomfortable on campus. One example I always take is the house meetings. First years are completely separated, meetings are done in Afrikaans, there is no diversity in the mentality, some house meetings start with prayer. That is why I started leading a day residence, which took a lot of time. There are other examples of it, of F1 people moving to leadership positions, though it is difficult to put yourself out for an official position. You may also lose which is why some simply return and concentrate on their studies.'

He has some outspoken ideas about the diversity within the F1 programme. Although it is explicitly a programme that targets black and female leadership, it is predominantly white males who emerge during and after the programme:

'Why do black students not apply? It is a cultural issue; for them it is big thing to travel, leaving your parents. Something that is perhaps not as much present in black culture as it is in white culture. Within the groups it seems also that blacks seeks blacks, and whites seeks whites. Perhaps because we meet each other only one or two times before leaving, and don't get used to meeting each other before.'

This last remark about black people and white people meeting for the first time via a programme like F1 is illustrative of the differences in the cultures of black and white people. Bryson's It's a Black and White Thing describes the first steps of the UFS transformation project and is hopeful about the future. She is also very clear about the presence of deeply rooted identities when she quotes a white student telling that 'I'm more comfortable in my own skin' (2014:81). Yet, this same student thinks the programme has at least broadened his horizon.

John is clear about the programme's contribution to transformation:

'For me it does, I'm an example myself. It is an amazing program, because it is about learning new ideas. And it is these ideas that helped me take on leadership positions. In the SRC I had to defend the $\mathrm{F} 1$, because the program it costs a lot much money for relatively few students and that money could be used for other purposes. SRC people don't always value the long-term investment, because they give political priority to the easy-tosolve short-term issue they encounter. It is my job to politically defend the program, and help refine it.'

Like Dino, whom we will hear in the next narrative, John has a political take on transformation, but, in contrast to Dino, he resists working along what he believes to be short-term party political lines. He is clearly in search of alternative paths, that are - as other F1 students confirm - not easily available. John's attitude is shared by students who are critical of the F1 programme and have deliberately chosen not to go for a scholarship.

\section{The born leader}

Dino is one of a number of highly politicised economy students from one of the black residences, who, after taking part in the F1 programme, became a student leader with strong political ambitions. After having served in the residence committee, he was elected in the Student Representative Council, together with his residence mate. 
Like John, he is combining his studies with volunteer work at the Institute of Reconciliation, working on a study on transformation and student leadership:

'For this study we selected people who were leaders before 2010, when rector Jansen's transformation policy became effective; then we have a group of student leaders who became active in the years 2010-2012, the formative years of 'leadership for transformation'; and finally a group of leaders who are now operating with the consolidated knowledge generated in the previous two years. We consider leaders to be those who take positions in the residence councils, in the student associations, and in the SRC.'

For Dino, like many student leaders an active ANC member, the political and academic routes go together in a quest for personal development. Moreover, he is actively seeking to improve his knowledge and skills by applying for funded courses and training programmes nationally and internationally:

'For me transformation takes the political route, next to the academic path through the defense of student rights, and against those sectors in the university that are defending traditional vested [white] interests. I'd say you grow from one position to another.'

He maintains that the path he has taken is destined for him, and that the Amsterdam experience as an F1 group leader prepared him for his present tasks:

'For me it's another thing coming back and using what you learned. As a leader I have still a long way to go. So much to be tackled. There are so many senior students, staff, lecturers who are here from before Jonathan Jansen's time. They are from before the transformation agenda. We as F1's have learned that this must change, but many others are not yet there. They do resist transformation. Senior students, white staff, some do not see the need for transformation.'

His ideas on transformation are rather encompassing:

'It is not only race, or gender, it is about the whole outlook of the university, e.g. the residences. Interaction is limited, teaching is in different languages, which is not good for interaction. One medium of instruction would help.'

He is not fully positive about the F1 programme, however, as it serves only a small part of the first years:

'It has created an us versus them situation. Coming back you must have a significant impact, if you don't see that so, you should not be in the program. It is an investment. Not everybody does that, that is where the critics come in. One part is active, but others spoil the opportunity. The F1's should do more. I suggested the dean of students to improve the program. We should work more on getting to the white community on campus. Some of it is still very Afrikaans and conservative.'

Amsterdam has helped him to develop some ideas about himself, his identity and his future:

'We saw a lot of diversity in Amsterdam, unlike others who went to Japan, or China. We were privileged to conduct research in that diversity field, that was an experience. We were send into the field, the neighbourhoods. You could choose a research theme such as race, class, religion. Studying race in the Netherlands, that is of significance. I want to bring this experience further.'

After the interview he went off to his next SRC meeting. In the evening, he was sending out political messages on his cell phone: vote ANC in the coming elections. Dino represents a minority among the F1 students who see their participation in the programme as politically advantageous CV building. Dino is clear about his future work: he pursues a job in (preferably ANC) government administration.

\section{The careerist woman}

Not all F1 students take what they learned through the programme as the start of a leadership career. Anisha, a 21-year-old accounting student, has taken it first and foremost as an encouragement to become successful in society by pursuing a career with her university training. Yet, she has also learned from her participation:

'I have become a more open-minded person as a result of participating the program. In the two weeks that I was in Amsterdam I have seen homosexuals are people like myself. After my trip I told my friends that the people in Amsterdam are like this and like that. Now I think that a lot of my friends have adopted this mentality of open mindedness. That is how I believe I can make a change in the smallest way.'

Another eye-opener for her was the way the lectures were given in Amsterdam:

'Student cultures are way different, I discovered when I saw students from different studies really interacting with each other. That made me think that our world [in Bloemfontein] is a bit closed. This is also clear in my residence which is very Afrikaans.'

Yet, university leadership is not her cup-of-tea. She is in accounting and very determined to go for a career in banking, or investment management. Her studies, in combination with the broader horizon F1 gave her, has stimulated her career ambitions:

'I just don't have the time. I am going to Johannesburg, I am a bit tired of the Free State, I go to private university. Leadership in our field of accounting is different, task oriented. This is how I feel. Most of the F1's, coming back from the abroad tend to go for the leadership positions, e.g. in the residence council and they build up a sort of a fan base, which then helps for the SRC, yet they hardly partake in leadership outside of campus. That is where I will grow and become a successful professional. I am prepared to work hard for it.'

Anisha is one of several black students for whom the F1 participation clearly had a personal transformative and emancipatory effect, without striving to make a contribution to any form of collective struggle. She firmly believes that transformation can only be achieved by making a personal effort, and that particularly black students are individually responsible to move beyond the effects of an underlying culture of whiteness by pursuing a (business) career (Steyn 2001; see also Haffajee 2015). 


\section{Conclusion and discussion}

The seven UFS student self-identity narratives presented show how diverse the discursive positioning vis-à-vis South Africa's societal and institutional transformation process after more than 25 years still is. The leadership programme the students participated in clearly made them aware of their responsibility to contribute to changing, and they all acknowledge that the programme has changed them at a personal level. Some have become more critical and reflective, while others started to explore more active ways of 'making a contribution'. The transformation concept clearly does not mean the same to all of them; the identity work they display in their narratives on self and others (Jenkins 2008) does not lead to one, or even more, central, distinctive and enduring group identities either (Albert \& Whetten 1985). Some narratives reveal a more robust and coherent self-identity, particularly the more politically inspired ones, while others show more ambiguous and insecure positions. In that sense, the F1 students here presented reflect the kind of self-identity pattern - from self-doubter to the more soldier-like type, with individual and contextual orientations, respectively - that Alvesson (2010) described. All students are storytellers, that is, they discursively make sense of their view on the transformation project, and what transpires from all these stories is that the programme - and especially their abroad trip to Amsterdam has widened their horizon beyond the culture of the provincial academic institution they had just entered. The adoption of a broader vision made them reflect on two related issues in particular that they feel is hampering change/transformation: language and colour (race). In various ways, all students refer to the effects of racialised society, and the still largely racialised university more in particular. It is no coincidence that the student protests that started in 2015 with the Rhodes-must-fall movement revolve around these same issues, although there are certainly more reasons for discontent. The unhappy marriage between language and race is particularly played out in the historically Afrikaans universities, including Bloemfontein, that scholars such as Steyn (2001) and Higgins $(2007 ; 2013)$ characterised as places of institutional whiteness. Whether this culture of whiteness still as prevalent as it was in pre-1994 South Africa can be doubted, but Jonathan Jansen's powerful analysis of white students' nostalgic embarrassment (based on student stories from the former Afrikaans University of Pretoria in the 1990s) has certainly lost some of its plausibility.

The self-identity narratives presented above largely confirm what Keet and Nel (2016), Walker and Loots (2016) as well as Jansen (2016) argue in their recent studies on the development of UFS democratic student citizenship over the last number of years. Walker and Loots studied asserts that all but a few students of the first F1 cohort positively responded to the space universities offer for reflecting on and responding to the transformation problem (2016:66). Jansen even attributed 'positive leadership' qualities to the students resulting from what he calls sensory leadership demonstrated by the (his!) university (2016). Keet and Nel also perceived progress among UFS student leaders, although they stress that 'too good to be true' outcomes perhaps need to be taken with caution, referring to what Bourdieu calls 'collusive objectification' (2016:137). They also point to the structuring force of habitus in the institutional field that tends to set limits to the likelihood of students taking up new responsibilities, as well as of researchers to be blinded by their own engagement (2016:139). Keet and Nel's study was based on interviews with students who served one or more terms in the student representative council of the university, which often proves to be a stepping stone for a political career. It was in the SRC positions that they experienced the institutional limits of transformation, which also comes to the fore in the present study. Keet and Nel's students mostly opted for the political (collective) route to change, the F1 students whose narratives I presented above display a broader array of options, including non-political and individual pathways.

The contribution of the self-identity narratives based approach taken in this contribution must, however, primarily be sought in their plurivocality. The narratives show that universities - and particularly those who are changing - are crucial places to capture identity work and subject positioning in different shapes. It is this kind of contextsensitive 'tales of the field' (Van Maanen 2010) that can help understand how the complex notion of transformation is evoked and interpreted in institutions of higher education. If the varying degrees of engagement the F1 students' selfidentity narratives display demonstrate anything, it is that transformation is not only a contested but also a socially, culturally and politically complex and multifaceted process.

In February 2016, confrontations during a rugby match on the Bloemfontein campus between students, their families and most probably interested factions from outside of the university was followed by a number of further irregularities that other universities in South Africa had already suffered before. ${ }^{2}$ In the subsequent months, there has been much talk on 'decolonising' the university, but few concrete steps have been made, as deeply rooted ideas and practices do not permit easy ways out, or forward, as Maré's Declassified (2014) compellingly shows with regard to South Africa's persistent racialism. It is likely, however, that the storytelling F1 students' identity work, and the ensuing practices, will give shape to transformation.

\section{Acknowledgements Competing interests}

The author declares that he has no financial or personal relationships which may have inappropriately influenced him in writing this article.

2.The photo in Figure 1 shows the besieged character the Bloemfontein campus attained from its leadership's decision to fence the place with barbed (razor) wire. 


\section{References}

Aina, T.A., 2010, 'Beyond reforms: The politics of higher education transformation in Africa', African Studies Review 53(1), 21-40. http://dx.doi.org/10.1353/ arw.0.0290

Albert, S. \& Whetten, D., 1985, 'Organizational identity', Research in Organizational Behavior 7, 263-295.

Alvesson, M., 2010, 'Self-doubters, strugglers, storytellers, surfers and others: Image of self-identities in organization studies', Human Relations 63(2), 193-217. http:// dx.doi.org/10.1177/0018726709350372

Balintulo, M., 2003, 'The role of the state in the transformation of South African higher education, 1994-2002: Equity and redress revisited', in P.T. Zeleza \& A Olukoshi (eds.), African universities in the twenty-first century, vol. II Knowledge and Society, pp. 441-458, CODESRIA, Dakar.

Bate, S.P., 1997, 'Whatever happened to organizational anthropology? A review of the field of organizational ethnography and anthropological studies', Human Relation 50(9), 1147-1171. http://dx.doi.org/10.1177/001872679705000905

Bate, S.P., 2004, 'The role of stories and storytelling in organizational change efforts: The anthropology of an intervention within a UK hospital', Intervention Research $1(1), 27-42$

Beech, N. \& Macintosh, R., 2012, Managing change. Enquiry \& action, Cambridge UP, Cambridge.

Boje, D.M., 1995, 'Stories of the storytelling organization: A postmodern analysis of Disney as "Tamara-land"', Academy of Management Journal 38(4), 997-1035. http://dx.doi.org/10.2307/256618

Boje, D.M., 2008, Storytelling Organizations, Sage, Thousand Oaks, CA.

Brink, C., 2010, 'Quality and equality in higher education', in keynote address at the Conference, University 2010: Making a Difference, Amsterdam, 22-23rd March (unpublished paper)

Brown, A.D, Gabriel, Y. \& Gherardi, S., 2009, 'Storytelling and change: An unfolding story', Organization 16(3), 323-333. http://dx.doi.org/10.1177/135050840

Brown, A.D. \& Humphreys, M., 2003, 'Epic and tragic tales: Making sense of change', Journal of Applied Behavioural Science 39(2), 121-144. http://dx.doi.org/10. 1177/0021886303255557

Brown, A.D., Patrick, S. \& Nandhakumar, J., 2008, 'Making sense of sensemaking narratives', Human Relations 61(8), 1035-1062. http://dx.doi.org/10.1177/001 8726708094858

Bryson, D., 2014, It's a black and white thing, Tafelberg, Cape Town.

Chetty, N. \& Merrett, C., 2014, The struggle for the soul of a South African university, University of Kwazulu-Natal, Durban.

Cloete, N., 2014, 'The South African higher education system: Performance and policy', Studies in Higher Education 39(8), 1355-1368. http://dx.doi.org/10.1080/ 03075079.2014.949533

Council on Higher Education, 2007, Review of higher education in South Africa, The Council on Higher Education, Pretoria.

Cross, M., 2004, 'Institutionalising campus diversity in South African higher education Review of diversity scholarship and diversity education', Higher Education 47 387-410. http://dx.doi.org/10.1023/B:HIGH.0000020854.04852.80

Czarniawska, B., 1997, Narrating the organization, University of Chicago Press, Chicago, IL.

Czarniawska, B., 2007, Shadowing: And other techniques for doing fieldwork in modern societies, Copenhagen Business School, Copenhagen.

Department of Education, 1997, A programme for the transformation of higher education, Education white paper 3, Government Gazette, Pretoria.

Gabriel, Y., 2000, Storytelling in organizations. Facts, fictions, and fantasies, Oxford UP, Oxford.

Haffajee, F., 2015, What if there were no whites in South Africa?, Picador Africa, Johannesburg.

Higgins, J., 2007, 'Institutional culture as keyword', in Council of Higher Education (eds.), Review of higher education in South Africa, pp. 97-123, The Council on Higher Education, Pretoria.

Higgins, J., 2013, Academic freedom in a Democratic South Africa. Essays and interviews on higher education and the humanities, Wits University Press, interviews on
Johannesburg.

Humphreys, M. \& Brown, A.D., 2002, 'Narratives of organizational identity and identification: A case study of hegemony and resistance', Organization Studies 23(3), 421-447. http://dx.doi.org/10.1177/0170840602233005

Jansen, J., 2003, 'Mergers in South African higher education: Theorizing change in transitional contexts', Politikon: South African Journal of Political Studies 30(1), 27-50. http://dx.doi.org/10.1080/02589340308046

Jansen, J.D., 2004, 'Race and education after ten years', Perspective in Education 22(4), 117-128.

Jansen, J.D., 2009, Knowledge in the blood. Confronting race and the apartheid past, UCT Press, Cape Town.

Jansen, J.D., 2016, Leading for change: Race, intimacy and leadership on divided university campuses, Routledge, London.

Jansen, J.D., Bindi, N., Chalafu, S., Lethoko, M., Sehoole, C. \& Soobrayan, V., 2002, Mergers in higher education, lessons learned in transitional contexts, University of Mergers in higher educati
South Africa, Pretoria.

Jawitz, J., 2010, 'Race and assessment practice in South Africa: Understanding black academic experience', Race, Ethnicity and Education 15(4), 545-559. http://dx. doi.org/10.1080/13613324.2011.645568

Jenkins, R., 2008, Social identity, Routledge, London.
Kamsteeg, F., 2008, 'In search of a merged identity; the case of multi-campus NorthWest University, South Africa', TD The Journal for Transdisciplinary Research in Southern Africa 4(2), 431-451. http://dx.doi.org/10.4102/td.v4i2.162

Kamsteeg, F., 2011, 'Transformation as social drama: Stories about merging at North West University, South Africa', Anthropology Southern Africa 34(1\&2), 51-61. http://dx.doi.org/10.1080/23323256.2011.11500008

Kamsteeg, F. \& Wels, H., 2004, 'Anthropological perspectives on power, performance and organisational politics', Intervention. Journal of Culture, Organisation \& Management 1(1), 7-26.

Kamsteeg, F. \& Wels, H., 2012, 'Traveling ideas: Equality and power play around "Diversity" at North-West University (NWU), South Africa', International Journal of Business Anthropology 3(2), 88-106.

Kamsteeg, F. \& Ybema, S., 2009, 'Making the familiar strange: A case for disengaged ethnography', in S. Ybema, D. Yanow, H. Wels \& F. Kamsteeg (eds.), Organizational ethnography. Studying the complexities of everyday life, pp. 101-119, Sage, Lthnography.
London.

Keet, A. \& Nel, W., 2016, 'Rights, regulation and recognition: Studying student leaders' experiences of participation and citizenship within a South African University', International Journal of Educational Science 13(1), 129-144.

MacDonald, M., 2006, Why race matters in South Africa, University of KwaZulu-Natal Press, Pietermaritzburg.

Maré, G., 2014, Declassified: Moving beyond the dead end of race in South Africa, Jacana Media, Auckland.

Paradeise, C. \& Thoenig, J.-C., 2013, 'Academic Institutions in search of quality: Local orders and Global standards', Organization Studies 34(2), 189-218. http://dx.doi. org/10.1177/0170840612473550

Risberg, A., Tienari, J. \& Vaara, E., 2003, 'Making sense of a transnational merger: Media texts and the (re)construction of power relations', Culture and Organization 9(2), 121-137. http://dx.doi.org/10.1080/14759550302806

Roux, C. (ed.), 2012, Safe spaces. Human rights educations in diverse contexts, Sense Publishers, Rotterdam.

Seabi, J., Seedat, J., Khoza-Shangase, K. \& Sullivan, L., 2012, 'Experiences of University Students Regarding Transformation in South Africa', International Journal of Educational Management 28(1), 66-81. http://dx.doi.org/10.1108/IJEM-012012-0017

Soudien, C., 2008, Report of the Ministerial Committee on transformation and social cohesion and the elimination of discrimination in Public Higher Education Institutions, Government Printer, Pretoria.

Steyn, M., 2001, Whiteness isn't what it used to be. White identity in a changing South Africa, Suny Press, New York.

Sveningsson, S. \& Alvesson, M., 2003, 'Managing managerial identities: Organizational fragmentation, discourse and identity struggle', Human Relations 56(10) 1163-1193. http://dx.doi.org/10.1177/00187267035610001

Tabensky, P. \& Matthews, S., 2015, Being at home, University of KwaZulu-Natal Press, Durban.

Thomas, R. \& Hardy, C., 2011, 'Reframing resistance to organizational change', Scandinavian Journal of Management 27, 322-331. http://dx.doi.org/10.1016/j. scaman.2011.05.004

Thomas, R., Sargent, L.D. \& Hardy, C., 2011, 'Managing organizational change: Negotiating meaning and power-resistance relations', Organization Science 22(1), 22-41. http://dx.doi.org/10.1287/orsc.1090.0520

Tsoukas, H. \& Jo Hatch, M., 2001, 'Complex thinking, complex practice: The case for a narrative approach to organizational complexity', Human Relations 54(8), 979-1013. http://dx.doi.org/10.1177/0018726701548001

University of the Free State, 2016, Leadership for Change Programme. Website University of the Free State, viewed 30 January 2016, from http://www.ufs.ac.za/

University of the Free State (2016) Vision. Website University of the Free State, viewed 30 January 2014, from http://www.ufs.ac.za/about-the-ufs/ufs-in-focus/ vision-mission-and-values

Vaara, E., 2002, 'On the discursive construction of success and failure in narratives of post-merger integration', Organization Studies 23(2), 211-248. http://dx.doi. org/10.1177/0170840602232003

Vaara, E., 2003, 'Post-acquisition integration as sensemaking: Glimpses of ambiguity, confusion, hypocrisy, and politicization', Journal of Management Studies 40(4), confusion, hypocrisy, and politicization', Journal of Mand
859-894. http://dx.doi.org/10.1111/1467-6486.00363

Van Maanen, J., 2010, 'A song for my supper. More tales of the field', Organizational Research Methods 13(2), 240-255. http://dx.doi.org/10.1177/1094428109343968

Van de Ven, A.H., 2007, Engaged scholarship: A guide for organizational and social research, Oxford University Press, Oxford.

Verwey, C. \& Quayle, M., 2012, 'Whiteness, Racism, and Afrikaner identity in postApartheid South Africa', African Affairs 111(445), 551-575. http://dx.doi.org/10. 1093/afraf/ads056

Walker, M., 2005a, 'Race is nowhere and race is everywhere: Narratives form black and white South African university students in post-apartheid South Africa', British Journal of Sociology of Education 26(1), 41-54. http://dx.doi.org/10.1080/014 Journal of Sociology of

Walker, M., 2005b, 'Rainbow Nation or New Racism? Theorizing race and identity formation in South African Higher Education', Race Ethnicity and Education 8(2), 129-146. http://dx.doi.org/10.1080/13613320500110501

Walker, M. \& Loots, S., 2016, 'Social citizenship formation at university: A South African case study', Compare: A Journal of Comparative and International Education 46(1), 48-68. http://dx.doi.org/10.1080/03057925.2014.884920

Watson, T.J., 2008, 'Managing identity: Identity work, personal predicaments and structural circumstances', Organization 15(1), 121-143. http://dx.doi.org/10.
$1177 / 1350508407084488$ 